\title{
PENGEMBANGAN MEDIA SCRAPBOOK PADA KETERAMPILAN MENULIS SISWA KELAS IV SD MUHAMMADIYAH KARANGBENDO
}

\author{
Oktafia Tri Hapsari, Yosi Wulandari \\ PGSD, FKIP, Universitas Ahmad Dahlan \\ JL. Ki Ageng Pemanahan No. 19, Yogyakarta, Indonesia \\ e-mail: oktafiahapsari96@gmail.com
}

\begin{abstract}
This study aims to determine the procedure for developing scrapbook media on the writing skills of fourth grade elementary school students of fiction story material, as well as knowing the feasibility of scrapbook media on the writing skills of fourth grade elementary school students. This research is included in the research (R\&D) by using the ADDIE development model with the following stages 1) Analysis, 2) Design, 3) Development, 4) Implementation, 5) Evaluation. The subject of the trial was conducted by media experts, material experts, learning experts, students and teachers. Data collection is done by questionnaire, interview and documentation. Data analysis uses qualitative data analysis and quantitative data. The results of the study of the validation of $85 \%$ of media experts with excellent categories. the results of the validation of the material experts $89.6 \%$ with a very good category. The results of validation from learning experts $82.7 \%$ with very good category. The results of the teacher's response to the small group trial $95 \%$ with a very good category, student responses to the small group trial $94 \%$ with a very good category. The results of the teacher's response to the large group trial 95\% with a very good category, student responses to the large group trial $96.8 \%$ with a very good category. The results showed that (1) the scrapbook learning media was produced in writing skills, (2) the results of the entire product trial were categorized very well with a score of 91.2. These results indicate that the scrapbook media is suitable for use in the learning process and supports students' writing skills.
\end{abstract}

Keywords: Scrapbook, Writing, Fiction

\begin{abstract}
ABSTRAK
Penelitian ini bertujuan untuk mengetahui prosedur pengembangan media scrapbook pada keterampilan menulis siswa kelas IV SD materi cerita fiksi, serta mengetahui kelayakan media scrapbook pada keterampilan menulis ssiwa kelas IV SD. Penelitian ini termasuk dalam penelitian (R\&D) dengan menggunakan model pengembangan ADDIE dengan tahap sebagai berikut 1)Analysis, 2)Design, 3) Development, 4) Implementation, 5) Evaluation. Subjek uji coba dilakukan oleh ahli media, ahli materi, ahli pembelajaran, siswa dan guru. Pengumpulan data dilakukan dengan kuisioner, wawancara dan dokumentasi. Analisis data menggunakan analisis data kualitatif dan data kuantitatif. Hasil penelitian dari validasi ahli media $85 \%$ dengan kategori sangat baik. hasil validasi dari ahli materi 89,6\% dengan kategori sangat baik.
\end{abstract}


Hasil validasi dari ahli pembelajaran $82,7 \%$ dengan kategori sangat baik. Hasil tanggapan guru pada uji coba kelompok kecil 95\% dengan kategori sangat baik, respon siswa pada uji coba kelompok kecil 94\% dengan kategori sangat baik. Hasil tanggapan guru pada uji coba kelompok besar $95 \%$ dengan kategori sangat baik, respon siswa pada uji coba kelompok besar 96,8\% dengan kategori sangat baik. Hasil penelitian menunjukkan bahwa (1) telah dihasilkan media pembelajaran scrapbook pada keetrampilan menulis, (2) hasil keseluruhn uji coba produk berkategori sangat baik dengan skor 91,2. Hasil tersebut menunjukan bahwa media scrapbook layak untuk digunakan dalam proses pembelajaran serta mendukung keterampilan menulis siswa.

Kata kunci: Scrapbook, Menulis, Fiksi

\section{PENDAHULUAN}

Dunia pendidikan mencanangkan keberhasilan proses belajar mengajar sebagai tujuan utama yang harus dicapai. Tujuan utama dalam dunia pendidikan yang diinginkan tersebut dapat tercapai apabila sekolah mampu mempadukan antara kegiatan guru dengan siswa dalam pelaksanaan kegiatan belajar mengajar. Sebagai pengajar, guru hendaknya memiliki perencanaan pengajaran yang cukup matang.

Proses pembelajaran dapat terwujud apabila didukung oleh guru yang dapat memahami kondisi kelas dengan menciptakan pembelajaran yang bermakna. Pembelajaran yang bermakna ini bisa diwujudkan dengan cara guru harus mampu meramu berbagai komponen pembelajaran seperti pemilihan metode atau media yang tepat untuk setiap materi pembelajaran. Pembelajaran yang termasuk dalam hal ini adalah materi pada mata pelajaran Bahasa Indonesia. Bahasa Indonesia merupakan mata pelajaran yang wajib diajarkan pada setiap jenjang pendidikan, baik pada pendidikan dasar, pendidikan menengah, maupun perguruan tinggi.

Proses pembelajaran Bahasa Indonesia meliputi empat aspek penting yaitu keterampilan menyimak, keterampilan berbicara, keterampilan membaca, dan keterampilan menulis (Tarigan, 2008:1). Setiap keterampilan pada dasarnya memiliki hubungan erat dan saling mempengaruhi. Sebelum memiliki keterampilan menulis, seseorang haruslah memiliki kebiasaan membaca karena menulis dan membaca sebagai aktivitas komunikasi yang saling melengkapi (Saddhono, 2014:149).

Menulis merupakan salah satu dari keempat aspek keterampilan bahasa yang dapat dipelajari. Bagi banyak orang keterampilan menulis bukanlah hal yang mudah dan menyenangkan. Sebagaimana dikemukakan oleh (Dalman, 2015:5), menulis adalah sebuah proses mengait-ngaitkan antara kata, kalimat, paragraf maupun antara bab secara logis agar dapat dipahami. Proses tersebut mendorong seseorang untuk menulis dengan berfikir secara sistematis dan logis serta kreatif agar dapat dipahami dengan mudah.

Berdasarkan hasil observasi yang dilakukan pada bulan Agustus 2018 di SD Muhammadiyah Karangbendo, proses pembelajaran menulis belum maksimal. Metode pembelajaran yang digunakan guru belum bervariasi, yaitu cenderung menggunakan metode ceramah dan kurang menggunakan media. Dengan demikian, peran guru sangat dibutuhkan dalam mengembangkan motivasi siswa dalam menulis dan memberikan inovasi suatu pembelajaran. Media pembelajaran yang ada dimaksudkan agar menumbuhkan minat menulis siswa. Upaya tersebut dapat dilakukan oleh guru yaitu dengan penggunaan metode dan media pembelajaran yang menunjang minat menulis. Seperti pendapat yang dikemukakan oleh Munadi dalam Sufanti (2010:62), media 
pembelajaran adalah segala sesuatu yang dapat menyampaikan dan menyalurkan pesan dari sumber secara terencana sehingga tercipta lingkungan belajar yang kondusif di mana penerimanya dapat melakukan proses belajar secara efektif dan efisien.

Berdasarkan hasil wawancara pada tanggal 29 Agustus 2018 di SD Muhammadiyah Karangbendo, guru mengatakan bahwa keterampilan guru dalam membuat media pembelajaran untuk dijadikan bahan penunjang dalam pembelajaran masih rendah. Selain itu, guru juga menyampaikan bahwa masih kurangnya referensi buku ataupun media pembelajaran yang dimiliki oleh guru atau sekolah tentang materi cerita fiksi mata pelajaran Bahasa Indonesia kelas IV. Setelah itu, dilakukan wawancara kepada siswa tentang bagaimana pemahaman siswa tentang materi cerita fiksi pada mata pelajaran Bahasa Indonesia. Hasilnya adalah bahwa siswa kelas IV dalam mempelajari materi tersebut belum terlalu paham karena guru hanya menceritakan saja tentang materi tersebut. Belum adanya gambar ataupun buku-buku yang membantu siswa untuk memahami materi tersebut. Hal itu juga yang menghambat motivasi siswa dalam keterampilan menulis cerita fiksi. Berdasarkan hasil observasi ditemukan guru kelas IV belum terampil dalam mengembangkan suatu media pembelajaran dan kurangnya referensi media pembelajaran ataupun bahan ajar yang terdapat dalam perpustakaan sehingga berpengaruh pada penyampaian materi mata pelajaran tersebut.

Berkembangnya produk inovatif yang pada dunia pendidikan salah satunya yaitu media pembelajaran. Media pembelajaran memiliki banyak ragam yang telah dikembangkan salah satunya yaitu media pembelajaran dalam bentuk cetak. Media pembelajaran berbentuk cetak memiliki banyak ragam salah satunya yaitu Scrapbook. Scrapbook berasal dari bahasa inggris, "scrap" yang berarti sisa, carik, atau potongan. Sedangkan "book" berarti buku. Scrapbook biasanya digunakan untuk membuat album kenangan yang memuat bukan hanya foto akan tetapi berbentuk kliping atau catatan penting yang berhubungan dengan momen penting Wahyu (2018: 124). Sejalan dengan pendapat Hardiana dalam Damayanti (2017: 805) bahwa buku tempel atau dikenal dengan scrapbook adalah sekumpulan foto, catatan, cerita, narasi, puisi, dan lain sebagainya yang dirangkai dan disusun dalam sebuah album hand made book. Namun, seiring dengan perkembangan zaman, scrapbook dapat digunakan untuk berbagai macam kebutuhan, salah satunya sebagai media pembelajaran. Oleh karena itu, media scrapbook dipilih sebagai alasan penelitian pengembangan karena di SD Muhammadiyah Karangbendo belum tersedia media scrapbook dalam pembelajaran Bahasa Indonesia.

Berdasarkan permasalahan di atas, dapat disimpulkan bahwa ada beberapa permasalahan yang timbul yaitu, (1) kurangnya keterampilan guru dalam membut media atau bahan ahar (2) kurangnya motivasi siswa dalam keterampilan menulis materi cerita fiksi (3) guru membutuhkan media pembelajaran yang digunakan untuk menjelasknamateri cerita fiksi (4) belum banyak medai pembelajaran yang dapat digunakan oleh guru pda sekolah tersebut untuk membantu menjelaskna materi cerita fiksi (5) belum adanya media scrapbook dalam materi cerita fiksi.

Permasalahan yang sangat menonjol yaitu tidak adanya media pembelajaran yang digunakan oleh guru pada saat proses pembelajaran. Padahal dengan adanya media yang kongkrit dapat membantu siswa untuk mempermudah proses pembelajaran yang maksimal. Sehingga dengan adanya pemilihan media scrapbook diharapkan siswa dapat melatih kemampuan menulis, karena dengan menggunakan media scrapbook akan membantu mempermudah guru dalam menyampaikan materi, terutama pada materi cerita fiksi. Media scrapbook berbentuk media cetak yang berukuran $30 \mathrm{~cm}$ x $21 \mathrm{~cm}$. Scrapbook merupakan karya kreatif hand made yang di desain dengan menggunakan teknik menempel. Di dalam scrapbook ini telah dihias dengan tampilan yang menarik untuk siswa pada saat 
menggunakannya. Scrapbook ini menggunakan materi pada pembelajaran Bahasa Indonesia yakni materi tentang cerita fiksi.

Kelebihan dari media scrapbook yaitu mudah dalam menyiapkan media, mudah dalam menggunakan media, menimbulkan daya tarik siswa, menciptakan suasana belajar sambil bermain, meningkatkan keterampilan menulis siswa. Selain itu media scrapbook juga dapat digunakan oleh guru sebagai suatu media pembelajaran untuk mempermudah dalam menyampaikan materi mengembangkan pembelajaran bahasa sesuai dengan usia siswa sehingga mendorong siswa untuk aktif dalam pembelajaran serta dapat menumbuhkan semangat belajar dan menimbulkan rasa gembira pada siswa. Adapun tujuan dari penelitian ini yaitu sebagai berikut: 1) mengetahui prosedur dalam pengembangan media scrapbook pada keterampilan menulis siswa kelas IV SD Muhammadiyah Karangbendo. 2) mengetahui kelayakan media scrapbook pada keterampilan menulis siswa kelas IV SD Muhammadiyah Karangbendo.

\section{METODE PENELITIAN}

Penelitian ini menggunakan metode penelitian dan pengembangan atau disebut juga dengan istilah Research and Development (R\&D). Pengembangan ini menggunakan desain pengembangan oleh Dick and Carry (1996) dengan model ADDIE yang terdiri atas lima langkah yaitu: (1) analisis (analysis), (2) perancangan (design), (3) pengembangan (development), (4) implementasi (implementation), dan (5) evaluasi (evaluation). Prosedur pengembangan yang akan peneliti lakukan dalam pengembangan media scrapbook ADDIE yang disesuaikan dengan kebutuhan peneliti. Prosedur pengembangan yang akan peneliti lakukan dalam pengembangan media scrapbook pada keterampilan menulis siswa kelas IV SD Muhammadiyah Karangbendo memodifikasi dari model pengembangan ADDIE. Pada penelitian pengembangan ini mengacu pada prosedur penelitian pengembangan ADDIE yang disesuaikan dengan kebutuhan peneliti.

Setelah tahapan langkah-langkah telah diketahui maka tahap selanjutnya yaitu mengujicobakan produk. Adapun tahapan dalam mengujicobakan produk yang perlu diketahui yaitu melalui desain uji coba, subjek coba, jenis data. Tahap desain uji coba, pada penelitian ini uji coba produk ditunjukan dengan beberapa langkah yaitu produk dicobakan kepada ahli media, ahli materi, dan ahli pembelajaran. Setelah mendapatkan penilaian dan saran, maka produk direvisi. Selanjutnya melakukan uji produk kepada siswa untuk memperoleh data kelayakan terhadap media pembelajaran scrapbook yang diperoleh dari hasil lembar kuisioner, juga diperoleh dari penilaian guru berdasarkan kuisioner yang telah diberikan.

Subjek uji coba dilakukan oleh ahli media, ahli materi, ahli pembelajaran, guru, dan siswa siswa kelas IV SD Muhammadiyah Karangbendo yang terdiri dari 27 siswa. 5 siswa sebagai uji coba kelompok kecil dan 22 siswa sebagai uji coba kelompok besar. Jenis data yang digunakan pada penelitian ini yaitu data kualitatif dan data kuantitatif. Instrumen pengumpulan data yaitu menggunakan kuisioner, wawancara, dan dokumentasi.

\section{HASIL DAN PEMBAHASAN}

Hasil yang diperoleh berdasarkan penelitian yang telah dilakukan yaitu melalui tahapan-tahapan ADDIE. Tahapan tersebut dimulai dari tahap Analisis (Analysis). Langkah analisis yang dilakukan oleh peneliti mencangkup tiga hal yaitu analisis permasalahan lapangan dan kebutuhan media, kurikulum, dan karakteristik siswa. Berdasarkan analisis permasalahan yang dialami oleh guru kelas IV adalah belum adanya media yang mendukung untuk mengajar materi cerita fiksi dalam pembelajaran Bahasa 
Indonesia. Selain itu, hasil dari wawancara yang dilakukan oleh peneliti pada siswa kelas IV adalah siswa masih kurang memahami materi cerita fiksi, terutama siswa masih kesulitan dalam menulis sendiri cerita fiksi menggunakan bahasanya sendiri. Penyebab kurangnya pemahaman pada materi tersebut adalah belum adanya media yang mendukung guru untuk menjelaskan materi serta mendukung keterampilan menulis siswa karena dalam pembelajaran guru masih menggunakan buku paket tematik saja.

Berdasarkan analisis kebutuhan yang telah dilakukan, penulis mnemukan solusi untuk mengatasi permasalahan guru dan siswa SD Muhammadiyah Karangbendo dengan mengembangkan media scrapbook pada keterampilan menulis materi cerita fiksi kelas IV Sekolah Dasar. Pengembangan media scrapbook ini juga bertujuan untuk memotivasi dan mengembangkan keterampilan menulis siswa. Selain itu, kurikulum yang digunakan di SD Muhammadiyah Karangbendo sudah menggunakan kurikulum 2013 dalam pembelajaran. Mata pelajaran Bahasa Indonesia merupakan mata pelajaran yang telah tergabung dalam pembelajaran tematik. Analisis kurikulum yang dilakukan yaitu untuk mengetahui Kompetensi Inti dan Kompetensi Dasar kelas IV Sekolah Dasar.

Tahap kedua dari model ADDIE adalah tahap perencanaan (design). Berdasarkan analisis kebutuhan melalui pengamatan yang telah dilakukan oleh peneliti, maka pada tahap ini dilakukan penyusunan perencanaan produk pembelajaran berupa media pembelajaran dan desain media scrapbook. Media scrapbook di desain untuk membantu guru dalam menyampaikan materi bagi siswa pada keterampilan menulis materi cerita fiksi. Media scrapbook ini dapat membantu mempermudah guru dalam menyampaikan materi dan membantu siswa pada keterampilan menulis. Hal-hal yang dapat dilakukan dalam perancangan produk adalah sebagai berikut. 1) Penyusunan kerangka media scrapbook, 2) Pemilihan format media, 3) Perancangan desain media scrapbook, 4) penyusunan desain instrumen penelitian. Hal pertama yang dilakukan dalam perencanaan (design) adalah penyusunan kerangka media secara garis besar (outline). Penyusunan kerangka media secara garis besar yaitu terdiri dari bagian I berupa halaman awal media, bagiam II berupa isi dari media scrapbook, serta bagain III berisi penutup. Penyusunan kerangka media bertujuan agar memudahkan dalam pengembangan produk. Kemudian melakukan pemilihan format media. Media scrapbook disusun menggunakan kertas yang berbeda jenis. Pada tas/paperbag menggunakan kertas art cartoon $230 \mathrm{gsm}$, bagian cover menggunakan kertas karton yang dilapisi kertas ivory 230 gsm dengan laminasi glossy, isi scrapbook menggunakan kertas ivory 230 gsm selain itu menggunakan kertas hammer, kertas bc, dan kertas manila.media scrapbook ini memuat materi cerita fiksi. Setelah menentukan format yang akan digunakan, hal selanjutnya yaitu merancang desain media scrapbook atau storybord. Penyusunan desain storyboard bertujuan agar desain yang telah dirancang sesuai dengan apa yang sudah direncakan dengan matang. Langkah yang terakhir yaitu penyusunan desain instrumen. Instrumen penelitian berupa lembar instrumen ahli media, ahli materi, ahli pembelajaran, lembar angket respon guru, dan lembar angket respon siswa. Lembar angket validator ahli dan angket respon guru menggunakan skala likert. Lembar angket terdiri dari 4 pilihan yaitu 1, 2, 3, dan 4, sedangkan lembar angket respon siswa menggunakan keterangan "ya" atau "tidak" dengan skor 1 dan 0.

Tahap ketiga yaitu Pengembangan (Development). Pada tahap pengembangan ini meliputi pra penulisan, penyusunan scrapbook dan tahap pembuatan scrapbook. Pada tahap ini, media scrapbook mulai dikembangkan sesuai dengan desain yang telah dibuat. Dalam penyajian materi yang digunakan dalam media scrapbook dilakukan dengan menggunakan berbagai sumber dan referensi serta gambar-gambar yang berhubungan dengan materi cerita fiksi. Sumber yang digunakan dalam membuat scrapbook cerita fiksi diantaranya buku tematik siswa K13 kelas IV, buku tematik guru k13 kelas IV serta buku 
cetak yang memuat materi cerita fiksi. Setelah itu scrapbook disusun berdasarkan storyboard yang telah dibuat. Scrapbook ini disusun agar memudahkan siswa dalam memahami materi cerita fiksi pada keterampilan menulis. Selain itu kegiatan menyiapkan material/bahan yang diperlukan sesuai spesifikasi produk yang dikembangkan. Selanjutnya media scrapbook akan divalidasi oleh ahli media, ahli materi dan ahli pembelajaran. Pada tahap pengembangan maka perlu mempersiapkan alat, bahan, dan aplikasi yang digunakan dalam pembuatan media scrapbook. Kemudian langkah selanjutnya validasi dilakukan oleh ahli media, ahli materi, dan ahli pembelajaran yaitu dosen PGSD. Dosen yang menjadi ahli merupakan dosen yang berkompeten di bidangnya. Setelah divalidasi, maka adanya penyempurnaan (revisi produk) yang dikembangkan. Selanjutnya jika produk sudah direvisi maka dilanjutkan ke tahap berikutnya.

Tahap keempat yaitu Pelaksanaan (Implementation), setelah dilakukan penilaian media scrapbook oleh beberapa ahli, maka selanjutnya akan dilakukan revisi produk sebelum diujicobakan ke Sekolah Dasar sesuai saran dan masukan yang diberikan oleh beberapa ahli. Setelah produk direvisi dikatakan layak uji coba, maka langkah selanjutnya adalah melakukan uji coba produk dengan subjek uji coba yaitu siswa kelas IV SD Muhammadiyah Karangbendo. Pengambilan data dilakukan dengan uji coba kelompok kecil yang berjumlah 5 siswa dan uji coba kelompok besar yang berjumlah 22 siswa. Peneliti menyebarkan kuisioner respon kepada guru dan siswa di kelas IV SD Muhammadiyah Karangbendo. Hal ini dilakukan untuk mendapatkan data terkait kelayakan media srapbook.

Tahap yang kelima yaitu Evaluasi (Evaluation), pada tahap ini setelah media scrapbook diuji coba, maka akan dilakukan evaluasi terhadap produk pengembangan media scrapbook. Evaluasi dilakukan oleh peneliti dengan menganalisis data hasil penelitian yang diperoleh, yaitu kelayakan Scrapbook Cerita Fiksi dari dosen ahli, guru, dan siswa. Selain itu juga melakukan evaluasi mulai pengembangan produk hingga media pembelajaran scrapbook dapat dikatakan layak.

Data yang diperoleh dari hasil penelitian ini berupa data kualitatif dan data kuantitatif. Data kualitatif berupa komentar atau saran dari ahli media, ahli pembelajaran, ahli materi, respon siswa, dan respon guru. Sedangkan data kuantitatif digunakan untuk mengolah data yang diperoleh dari hasil validasi berupa skor oleh ahli media, ahli materi, ahli pembelajaran, angket respon guru, dan respon siswa. Adapun data yang diperoleh dari penilaian para ahli sebagai berikut.

1. Data Hasil Validasi Ahli Media

Hasil validasi ahli media, skor maksimal dari kuisioner ahli media adalah 60 . Jumlah skor yang didapat dari ahli media adalah 51, sehingga presentase yang diperoleh adalah 85,0\% dan termasuk dalam kategori "Sangat Baik" pada hasil penilaian ahli pembelajaran terhadap kualitas media scrapbook.

2. Data Hasil Validasi Ahli Materi

Hasil validasi ahli materi, skor maksimal dari kuisioner ahli materi yang adalah 48. Jumlah skor yang didapat dari ahli materi adalah 43, sehingga presentase yang diperoleh adalah $89,6 \%$ dan termasuk dalam kategori "Sangat Baik" pada hasil penilaian ahli materi terhadap kualitas media scrapbook.

3. Data Hasil Validasi Ahli Pembelajaran

Hasil validasi ahli pembelajaran, skor maksimal dari kuisioner ahli pembelajaran adalah 52. Jumlah skor yang didapat dari ahli pembelajaran adalah 43, sehingga presentase yang diperoleh adalah $82,7 \%$ dan termasuk dalam kategori "Sangat Baik" pada hasil penilaian ahli pembelajaran terhadap kualitas media scrapbook. 
Tabel 1. Hasil Penilaian Ahli Terhadap Media Scrapbook

\begin{tabular}{llll} 
No & \multicolumn{1}{c}{ Penilaian } & Nilai & Kategori \\
\hline 1. & Ahli Media & 85,0 & Sangat Baik \\
\hline 2. & Ahli Materi & 89,6 & Sangat Baik \\
\hline 3. & Ahli Pembelajaran & 82,7 & Sangat Baik \\
\hline Jumlah & & $\mathbf{2 5 7 , 3}$ \\
\hline Rata-rata & & $\mathbf{8 5 , 8 \%}$ \\
\hline Kategori & & Sangat Baik
\end{tabular}

4. Data Hasil Respon Guru dan Siswa Pada Kelompok Kecil

a. Penilaian Guru

Hasil penilaian guru, skor maksimal dari lembar kuisioner penilaian guru adalah 40. Jumlah skor yang didapat dari penilaian guru adalah 38, maka persentase yang didapat dari penilaian guru adalah $95 \%$ dan mendapat penilaian dengan kategori " Sangat Baik" pada hasil penilaian guru terhadap kualitas media scrapbook.

b. Respon Siswa

Hasil respon siswa, skor maksimal dari lembar kuisioner respon siswa adalah 50. Jumlah skor yang didapat dari respon siswa adalah 47, maka persentase yang didapat dari respon siswa adalah $94,0 \%$ dan mendapat penilaian dengan kategori "Sangat Baik" pada hasil respon siswa terhadap kualitas media scrapbook. Seluruh nilai yang didapat dari guru dan siswa pada saat uji coba kelompok kecil adalah sebagai berikut.

Tabel 2. Hasil Penilaian Guru dan Respon Siswa Kelompok Kecil Terhadap Kualitas Media Scrapbook

\begin{tabular}{llcl} 
No & Penilaian & Nilai & \multicolumn{1}{c}{ Kategori } \\
\hline 1. & Penilaian Guru & 95 & Sangat Baik \\
\hline 2. & Respon Siswa & 94 & Sangat Baik \\
\hline Jumlah & $\mathbf{1 8 9}$ & \\
\hline Rata-rata & $\mathbf{9 4 , 5 \%}$ &
\end{tabular}

Kategori

Sangat Baik

5. Data Hasil Respon Guru dan Siswa Pada Kelompok Besar

a. Penilaian Guru

Hasil penilaian guru, skor maksimal dari lembar kuisioner penilaian guru adalah 40. Jumlah skor yang didapat dari penilaian guru adalah 38, maka persentase yang didapat dari penilaian guru adalah $95 \%$ dan mendapat penilaian dengan kategori "Sangat Baik" pada hasil penilaian guru terhadap kualitas media scrapbook. 
b. Respon Siswa

Hasil respon siswa, skor maksimal dari lembar kuisioner respon siswa adalah 220. Jumlah skor yang didapat dari respon siswa adalah 213, maka persentase yang didapat dari respon siswa adalah 96,8\% dan mendapat penilaian dengan kategori "Sangat Baik" pada hasil respon siswa terhadap kualitas media scrapbook. Seluruh nilai yang didapat dari guru dan siswa pada saat uji coba kelompok besar sebagai berikut.

Tabel 3. Hasil Penilaian Guru dan Respon Siswa Kelompok Besar

\begin{tabular}{llcc} 
No & $\quad$ Penilaian & Nilai & Kategori \\
\hline 1. & Penilaian Guru & 95 & Sangat Baik \\
\hline 2. & Respon Siswa & 96,8 & Sangat Baik \\
\hline Jumlah & $\mathbf{1 9 1 , 8}$ & \\
\hline Rata-rata & $\mathbf{9 5 , 9 \%}$ & \\
\hline Kategori & Sangat Baik
\end{tabular}

Setelah diketahui hasil kelompok kecil dan hasil kelompok besar, maka seluruh nilai yang didapat dari hasil kelompok kecil dan besar adalah sebagai berikut.

Tabel 4. Hasil Penilaian Guru dan Respon Siswa Terhadap Kualitas Media Scrapbook

\begin{tabular}{lccc} 
No & Penilaian & Nilai & Kategori \\
\hline 1. & Uji Kelompok Kecil & 94,5 & Sangat Baik \\
\hline $2 . \quad$ Uji Kelompok Besar & 95,9 & Sangat Baik \\
\hline Jumlah & $\mathbf{1 9 0 , 4}$ & \\
\hline Rata-rata & $\mathbf{9 5 , 2 \%}$ & \\
\hline Kategori & Sangat Baik &
\end{tabular}

Berdasarkan tabel diatas diperoleh jumlah rata-rata 95,2 menunjukan bahwa media scrapbook layak untuk digunakan di kelas IV SD untuk membantu pemahaman siswa terhadap materi cerita fiksi.

Berdasarkan hasil penelitian tersebut bahwa pengembangan media scrapbook layak digunakan di sekolah dasar sebagai referensi tambahan untuk membantu guru dalam menyampaikan materi pembelajaran. Pengembangan media scrapbook sangat bermanfaat bagi guru dan siswa. Hal ini dapat dilihat berdasarkan pembahasan berikut:

Pertama yaitu analisis data ahli media. Ahli media diperlukan dalam penelitian ini untuk mengetahui kelayakan media pembelajaran scrapbook. Hasil dari validasi media yang pertama mendapat nilai $66,7 \%$ dengan kategori "Baik". Adapun kritik dan saran dari dosen validasi ahli media yaitu sign/tanda untuk siswa gunakan masih perlu diperbaiki. Tambahkan gambar yang sesuai dengan bacaan. Tambahkan tas/paperbag agar lebih mudah untuk dibawa kemana-mana. Oleh karena itu peneliti melakukan revisi sesuai dengan kritik dan saran dari ahli media. Didapatkan hasil validasi ahli media yang kedua nilai sebesar 85,0\% dengan kategori "Sangat Baik" tanpa revisi. 
Kedua yaitu analisis data ahli materi. Ahli materi diperlukan dalam penelitian ini untuk mengetahui kelayakan materi pembelajaran yaitu cerita fiksi. Hasil dari validasi materi mendapat nilai 89,6\% dengan kategori "Sangat Baik". Adapun saran dan masukan dari ahli materi yaitu, penggunaan bahasa pada materi di lengkapi serta penggunaan bahasa pada teks cerita fiksi sudah baik.

Ketiga yaitu analisis data ahli pembelajaran. Validasi ahli pembelajaran dilaksanakan pada Hasil dari validasi pembelajaran mendapat nilai 82,7\% dengan kategori dengan kategori "Sangat Baik". Namun, terdapat saran dan masukan dari dosen validasi pembelajaran yaitu, perbaikan kata pada RPP serta lembar jawaban pada media dapat diganti supaya bisa ditulis dalam media langsung.

Keempat yaitu analisis data berdasarkan respon guru dan siswa. Guru wali kelas IV memberikan saran dan komentar yaitu, media yang digunakan sangat menarik, belum pernah digunakan anak-anak sebelumnya sehingga mereka sangat antusias. Kemudian siswa juga memberikan respon yaitu, media scrapbook menarik bagi siswa dan menciptakan pembelajaran yang menyenangkan. Siswa juga mengatakan bahwa motivasi siswa dalam menulis juga meningkat pada saat menggunakan media scrapbook dalam pembelajaran.

Analisis data kuantitatif berguna untuk mengolah data berupa angka yang diperoleh dari uji validasi media, validasi pembelajaran, validasi materi, penilaian guru, dan respon siswa. Adapun hasil data yang diperoleh dari masing-masing penilaian yaitu sebagai berikut:

Tabel 5. Hasil Keseluruhan Penilaian Terhadap Media Scrapbook

\begin{tabular}{clcl} 
No & \multicolumn{1}{c}{ Penilaian } & Nilai & \multicolumn{1}{c}{ Kategori } \\
\hline 1. & Ahli Media & 85,0 & Sangat Baik \\
\hline 2. & Ahli Materi & 89,6 & Sangat Baik \\
\hline 3. & Ahli Pembelajaran & 82,7 & Sangat Baik \\
\hline 4. & Uji Coba Kelompok Kecil & \\
\hline \multicolumn{2}{l}{ Guru } & 95,0 & Sangat Baik \\
\hline \multicolumn{2}{l}{ Siswa } & 94,0 & Sangat Baik \\
\hline 5. & Uji Coba Kelompok Besar & \\
\hline \multicolumn{2}{l}{ Guru } & 95,0 & Sangat Baik \\
\hline \multicolumn{2}{l}{ Siswa } & 96,8 & Sangat Baik \\
\hline Jumlah & & $\mathbf{6 3 8 , 1}$ \\
\hline Rata-rata & $\mathbf{9 1 , 2 \%}$
\end{tabular}

Kategori Sangat Baik




\section{SIMPULAN}

Penelitian telah dilakukan dengan menggunakan metode ADDIE. Tahapan pengembangan tersebut terdiri dari lima tahapan. Tahap pengembangan scrapbook yang pertama yaitu analisis (analysis). Tahap analisis dalam penelitian ini meliputi analisis permasalahan lapangan dan kebutuhan media, analisis kurikulum, dan karakteristik siswa. Tahap kedua yaitu perencanaan (design). Tahap perencanaan ini meliputi penyusunan kerangka media, pemilihan format, perencanaan desain media scrapbook, dan penyusunan desain instrumen penelitian. Tahap ketiga yaitu pengembangan (development). Pada tahap ini adalah pengembangan produk yang meliputi pra penulisan, penyusunan scrapbook, pembuatan media scrapbook, dan hasil uji coba validasi ahli. Tahap keempat yaitu pelaksanaan (implementation). Tahap pelaksanaan atau implementasi ini yang dilakukan yaitu uji coba produk kelompok kecil 5 orang siswa. Uji coba kelompok besar 22 siswa. Uji coba terhadap guru/respon guru. Tahap terakhir atu tahap kelima dalam penelitian pengembnagan ini yaitu evaluasi (evaluation). Tahap evaluasi ini, merupakan tahap mengevaluasi seluruh proses pengembangan produk hingga uji coba produk.

Media scrapbook pada keterampilan menulis siswa Kelas IV Sekolah Dasar berdasarkan hasil dari penilaian validator ahli menyatakan layak untuk digunakan. Hasil dari validasi media yaitu $85 \%$, validasi materi $89,6 \%$ dan validasi pembelajaran $82,7 \%$. Hasil penilaian respon guru kelompok kecil dan besar mendapatkan nilai $95 \%$. Hasil penilaian respon siswa mendapatkan hasil 94\% dalam skala kecil dan 96,8\% dalam skala besar. Hasil uji coba produk secara keseluruhan mendapat 91,2\%. Seluruh penilaian tersebut menunjukkan kriteria Sangat Baik.

\section{DAFTAR PUSTAKA.}

Dalman. 2015. Keterampilan Menulis. Jakarta: Raja Grafindo Persada

Damayanti, Maita. 2017. Pengaruh Media Scrapbook (Buku Tempel) Terhadap Hasil Belajar Siswa Materi Keragaman Rumah Adat di Indonesia Kelas IV Sekolah Dasar. Jurnal Penelitian Pendidikan Guru Sekolah Dasar, 5(3).Majid, A. (2014). Pembelajaran Tematik Terpadu. Bandung: PT Remaja Rosdakarya.

Saddhono, Kundharu dan Slamet. 2014. Pembelajaran Keterampilan Berbahasa Indonesia Teori dan Aplikasi. Yogyakarta: Graha Ilmu.

Sufanti, Main. 2010. Strategi Pengajaran Bahasa dan Sastra Indonesia. Surakarta: Yuma Pustaka.

Sugiyono. 2017. Metode Penelitian Pendidikan Pendekatan Kuantitatif, Kualitatif, dan R\&D. Bandung: Alfabeta.

Tarigan, Henry Guntur. 2008. Membaca Sebagai Suatu Ketrampilan Berbahasa. Bandung: Angkasa Bandung.

Tegeh, I Made, I Nyoman Jampel, dan Ketut Pudjawa. 2015. Model Penelitian Pengembangan. Yogyakarta: Graha Ilmu. Susanto, Ahmad. 2016. Teori Belajar dan Pembelajaran di Sekolah Dasar. Jakarta: Prenadamedia Group.

Wardhani, S, W. 2018. Pengembangan Media Scrapbook pada Materi Pengelompokan Hewan untuk Siswa Kelas III Sekolah Dasar. JS(Jurnal Sekolah. 2(2), 124-130. 